\title{
Sustainable Construction: Analysis of Its Costs and Financial Benefits
}

\author{
V. Sumateja Reddy \\ Student of Architecture, IGBC Accredited Professional and GRIHA Certified Professional, \\ Andhra University, Andhra Pradesh, India
}

\begin{abstract}
Buildings consume a significant amount of our natural resources and have a wide range of environmental impacts. These economical and environmental concerns are a key driver behind the sustainable design movement. Selecting eco friendly building materials and methods are one way to minimize a building's economical impact. In fact, energy efficiency reductions in the construction and operation of buildings, offers one of the most significant opportunities to reduce financial burden to owners. The main objective of this paper is illustrated how the sustainable or green buildings benefits and impact on the stakeholder.
\end{abstract}

Keywords: Buildings, $\mathrm{CO}_{2}$, Green Buildings, Goals, Economical Benefits

\section{INTRODUCTION}

Buildings including construction, operations and deconstruction impacts, use approximately $15 \%$ of the world's fresh water resources, $40 \%$ of the world's energy and produce approximately $30 \%$ of the world's greenhouse gas emissions. The analyst forecast global market to grow at a CAGR of $9.6 \%$ during the period 2016-2020.To prevent the worst effects of global climate change and minimize other negative environmental impacts, it is therefore important to address the environmental impacts of buildings.

Key financial benefits of new green construction generally relate to lower operational costs, lower energy, waste and water costs, lower maintenance costs, and increased productivity and health. The latter, while difficult to measure/ prove, have come to be regarded as the holy grail of green building given that labor costs for most businesses comprise the overwhelming majority of costs. Building green also presents opportunities for incentives to offset any higher initial (capital) costs and may result in increased occupancy rates and rental rates, insurance discounts and higher property value.

"Green" or "sustainable" buildings use key resources like energy, water, materials, and land much more efficiently than buildings that are simply built to code. They also create healthier work, learning, and living environments, with more natural light and cleaner air, and contribute to improved employee and health, comfort, and productivity. Sustainable buildings are cost-effective, saving taxpayer dollars by reducing operations and maintenance costs, as well as by lowering utility bills

Figure 3 Financial Benefits of Green Buildings Summary of Findings (per sft ) Source: Capital E Analysis Category

\begin{tabular}{|l|l|}
\hline Net Present Value Energy Savings & $\$ 5.80$ \\
\hline Emissions Savings & $\$ 1.20$ \\
\hline Water Savings & $\$ 0.50$ \\
\hline Operations and Maintenance Savings & $\$ 8.50$ \\
\hline Productivity and Health Benefits & $\$ 36.90$ to $\$ 55.30$ \\
\hline Subtotal & $\$ 52.90$ to $\$ 71.30$ \\
\hline Average Extra Cost of Building Green & $(-3.00$ to $-\$ 5.00)$ \\
\hline Total Net Benefit & $\$ 50$ to $\$ 65$ \\
\hline
\end{tabular}

\section{GOALS OF GREEN BUILDINGS}

The basic goal of green building is attractive, comfortable, affordable shelter that does no harm to the Earth in its manufacture, or its use or disposal. This overarching goal is driven by four further goals:

1. Reducing impacts on the Earth from constructing buildings and their materials

2. Reducing impacts which arise during occupancy

3. Reducing the impact of the structure at the end of its life

4. Creating a more desirable human experience

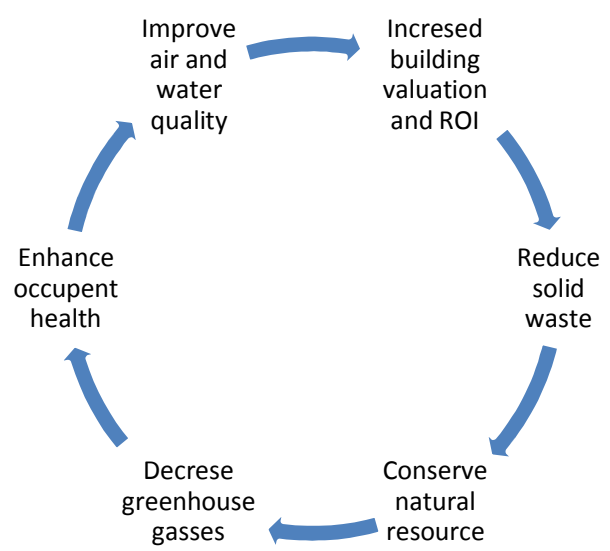

Figure 1: Goals of Green Buildings 


\section{TRIPLE BOTTOM-LINE BENEFITS}

Green building is not a simple development trend; it is an approach to building suited to the demands of its time, whose relevance and importance will only continue to increase. The benefits of green building are manifold, and may be categorized along three fronts: environmental, economic, and social.

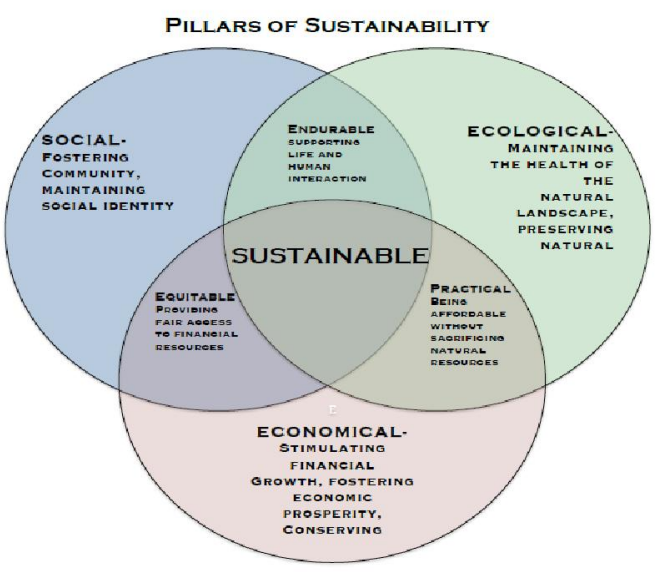

Figure 2: Benefits of sustainable construction

1. Environmental Benefits like Emissions Reduction. Water Conservation, Storm water Management, Temperature Moderation and Waste Reduction.

2. Economic Benefits like Energy and Water Savings, Increased Property Values, Decreased Infrastructure Strain, Improved Employee Attendance, Increased Employee Productivity, Sales Improvements, Development of Local Talent Pool.

\begin{tabular}{|l|l|}
\hline \multicolumn{2}{|c|}{$\begin{array}{c}\text { Table. } 1 \\
\text { Green building benefits (USGBC) }\end{array}$} \\
\hline $26 \%$ & Less energy \\
\hline $30 \%$ & Less Indore waste \\
\hline $50 \%$ & Less solid waste \\
\hline $33 \%$ & Less CO2 emission \\
\hline $30 \%$ & Less water usage \\
\hline
\end{tabular}

3.Social Benefits like Improved Health, Improved Schools, Healthier Lifestyles and Recreation.

\section{THE ECONOMICAL IMPACT OF BUILDINGS}

It is generally recognized that buildings consumes large amount of water, wood, energy and natural resources used in the economy. Green buildings provide a potential promising to help address a way of challenges facing globally, such as:

- The high cost of electric power.
- Worsening electric grid constraints, with associated power quality and availability problems.

- Pending water shortage and waste disposal issues.

- Growing concern over the cost of global warming.

- The rising incidence of allergies and asthma, especially in children.

- The health and productivity of workers.

- The effect of the physical school environment on children's abilities to learn and

- Increasing expenses of maintaining and operating state facilities over time.

According to the U.S. Environmental Protection Agency and the USGBC, construction and operation of the buildings results in the following consumption of resources:

- $72 \%$ of electricity resources

- $39 \%$ of total energy used

- $17 \%$ fresh water flows and

- Raw materials

As well, construction and operation of all buildings results in the following generation of waste materials:

- $25 \%-40 \%$ of municipal solid waste

- $50 \%$ of CFCs

- $\quad 35 \%$ of $\mathrm{CO}_{2}$ emission and

- Other air emissions and water discharge

A building is green in the true sense only when all the processes related to the building, throughout its life cycle, such as site planning, design, service design, construction, and operation, are environmental friendly and economical

\section{THE MAJOR FINALCIAL BENEFITS OF BUILDING GREEN FOR NEW CNSTRUCTION}

According to the Construction Marketplace SmartMarket Report, commercial green buildings have demonstrated an $8-9 \%$ decrease in operating cost, a $7.5 \%$ increase in building value and a $6.6 \%$ return on investment improvement. According to the Greening of Corporate America SmartMarket Report, commercial green buildings experience a $3.5 \%$ occupancy ratio increase and a $3 \%$ rent ratio increase. In a comparison of ENERGY STAR buildings and market comparables in the first quarter of 2008, ENERGY STAR buildings achieved 3.6\% higher occupancy rates. Green building is the practice of building or renovating structures to be energy and resource efficient throughout a building's life-cycle from sitting to design, construction, operation, maintenance, renovation and deconstruction. Green buildings use natural resources efficiently and fewer in quantity and reduce wastage, this leads to lower both utility bills and impact on the environment. These benefits range from being fairly predictable (energy, waste, and water savings) to relatively uncertain (productivity/health benefits). Energy and water 
savings can be predicted with reasonable precision, measured, and monitored over time. In contrast, productivity and health gains are much less precisely understood and far harder to predict with accuracy. The main benefits of building green are included the following:

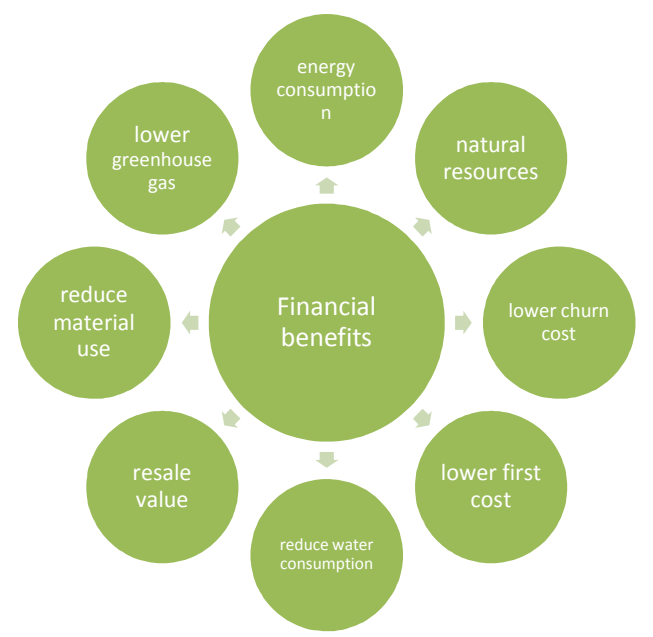

Figure 3: Economical benefits of green buildings

1. Reduce energy consumption

2. Decreased use of natural resources

3. Lower first costs

4. Lower churn cost

5. Annual water cost saving

6. Lower greenhouse gas emissions and air pollution

7. Improve attendance and improve productivity

8. Lower costs of facility maintenance and repair

9. Other benefits to the building owner and

10 . Indirect benefits to society

1. Reduce energy consumption Energy is a substantial and widely recognized cost of building operations that can be reduced through energy efficiency and related measures that are part of green building design. Green building energy savings primarily come from reduced electricity purchases and secondarily from reduced peak energy demand. On average, green buildings are $28 \%$ more efficient than conventional buildings and generate $2 \%$ of their power on-site from photovoltaic's (PV).

On average $25-30 \%$ more energy efficient ;Characterized by even lower electricity peak consumption ;More likely to generate renewable energy on-site; More likely to purchase grid power generated from renewable energy sources reduce heating, cooling, and lighting loads through climate-responsive design and conservation practices

- Employ renewable energy sources such as day lighting, passive solar heating, photovoltaic's, geothermal, and groundwater cooling
- Specify efficient HVAC and lighting systems that consider part-load conditions and utility interface requirements

- Optimize building performance by employing energy modeling programs and optimize system control strategies by using occupancy sensors $\mathrm{CO}_{2}$ sensors and other air quality alarms

- Monitor project performance through a policy of commissioning, metering, annual reporting, and periodic re-commissioning and

- Integrate water saving technologies to reduce the energy burden of providing potable water.

2. Decreased use of natural resources Green buildings also utilize fewer materials, through efficient design and elimination of unnecessary finish materials.

3. Lower first costs

Sustainable design team including the owners; designing team; landscape designers; O\&M staff; health, safety and security experts; the green contractor; cost consultants; occupant representatives needs work together from the start, seeking an integrated design. The team develops innovative solutions that meet energy, environmental, and social goals while keeping cost within budget.

\section{Lower churn cost}

Many sustainable buildings include a raised system that creates an under floor plenum used for HVAC air distribution modular partitions, modular work stations and modular power cabling and data systems can significantly reduce churn costs.

\section{Annual water cost saving}

Green building encourages innovative water-saving strategies that help projects use water wisely. Project teams can follow an integrated process to begin assessing existing water resources, opportunities for reducing water demand, and alternative water supplies. Effective strategies include:

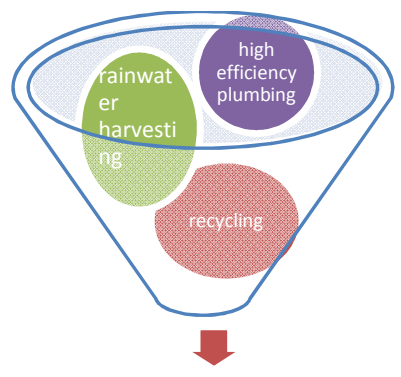

Water cost saving

Figure 4: Water cost saving 
- Switch to high-efficiency plumbing fixtures like ultralow-flow showerheads and faucets, dual flush toilets and no-water urinals.

- Install sub meters.

- Choose native and adapted plants

- Use xeriscaping.

- Select efficient irrigation technologies

- Water recycling or reuse measures and

- Methods reduce water use in HVAC systems

6. Lower greenhouse gas emissions and air pollution one set of environmental benefits from greening buildings that can be fairly easily estimated is a lower air pollutant and $\mathrm{CO}_{2}$ emissions. Emissions are reduced by decreasing energy use through energy-efficient design, use of renewable energy and HVAC system.

Table 2: Emission coefficients for energy consumption in commercial buildings

\begin{tabular}{|l|l|l|l|}
\hline & $\mathrm{SO}_{2}$ & $\mathrm{NO}_{2}$ & $\mathrm{CO}_{2}$ \\
\hline Natural Gas & Negligible & 0.08 & 15.8 \\
\hline Electricity & 0.97 & 0.45 & 55.62 \\
\hline
\end{tabular}

Sustainable design principles can significantly reduce these impacts

7. Lower absenteeism and improve productivity Sustainable design futures improve performance in attention and concentration level; improve performance on logical thinking tasks; improve organizational level performance; self rating of productivity.

8. Lower costs of facility maintenance and repair

Sustainable design aim s to increase durability and ease of maintenance.

- Using durable, long lasting can decrease maintenance cost and repairs

- Low VOC paints offers durability

- Using sustainable landscaping techniques decrease cost and

- Managing storm water with natural methods

9. Other benefits to the building owner

- Better worker retention and recruitment

- Lower cost of dealing with complaints

- Decreased risk, liability, and insurance rates

- Greater building longevity and

- Better resale value

10. Indirect benefits to society- The value $t$ society of environmental preservation and pollution reduction in municipal infrastructure requirements, local and regional economic growth

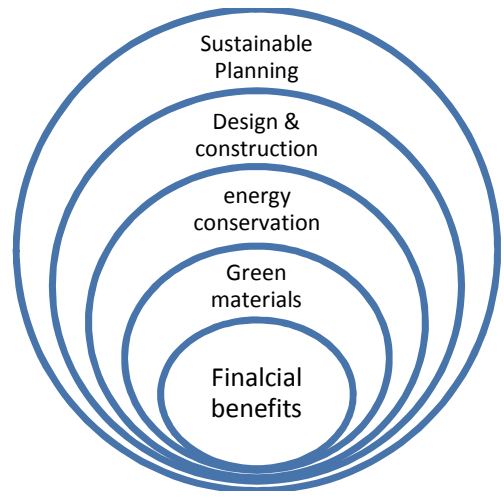

Figure 5: Financial benefits

\section{CONCLUSION}

Green building is the practice of building or renovating structures to be energy and resource efficient throughout a building's life-cycle from sitting to design, construction, operation, maintenance, renovation and deconstruction. The financial benefits of green buildings include lower energy, waste disposal, and water costs, lower environmental and emissions costs, lower operations and maintenance costs, and savings from increased productivity and health. This paper concludes that how the sustainable construction is benefit to all stakeholders.

\section{REFERENCE}

[1] http://www.usgbc.org/articles/green-building-facts.

[2] usgbc economic impact study sept,2015

[3] gbcsa.org.za/greenstar/greenstar.php.

[4]Dodge Data \& Analy.cs (2012). 2014 Dodge Construc2on Green Outlook Report..

[5]http://www.environmentalgraffiti.com/ecology/15-

living-walls-verticalgardens-sky-farms/1202.

[6]http://www.sciencedirect.com/science/article.

[7]http://www.legrand.com/EN/green-building-

description_12850.html.

[8]http://high-performancebuildings.org/tcil.php

http://www.worldenergyoutlook.org/media/weowebsite/20

15/IndiaEnergyOutlook WEO2015.

[9]U.S. Environmental Protection Agency. (October 28, 2009).Green Building Basic Information. Retrieved Dec2009, from http://www.epa.gov/ greenbuilding/pubs

[10] Green building impacts worker productivity. (2012). CAD/CAM Update, 24(5), 7-8.

[11] Pushkar, S., Becker, R., \& Katz, A.(2005). A methodology for design of environmentally optimal buildings by variable grouping. Building and Environment [12] Kats, Greg (2003, October) The Costs and Financial Benefits of Green Buildings: A Report to California's Sustainable Building Task Force. Retrieved from: h"p://www.calrecycle.ca.gov/greenbuilding/design/costben efit/report.pdf 